\title{
Contaminated blood case nears end
}

\section{The trial in Paris of four scientists for negligence in the protection of haemophiliacs from infection with HIV in the period 1983-85 will cast a long shadow over the links between science and the public service everywhere.}

Paris. After a month of hearings, the re-run of the great contaminated-blood trial is nearing its end, perhaps today (17 June). The lawyers hope, perhaps unreasonably, that by the end of the first week in July, there will be a second verdict on the guilt or innocence of the four scientists accused of having allowed blood products contaminated with HIV onto the French market during the first nine months of 1985. By then (but even earlier), techniques were available for preventing that state of affairs. In France, the most conspicuous victims were those then newly diagnosed with haemophilia, whose relatives have filled most of the public benches of No.13 Court in the Palais de Justice for the past month.

It is a curious setting for such a drama. No.13 Court might be a slightly shabby school-hall were it not for the high bench at one end behind which the three appeal judges sit. (There is also a reserve judge, in case another should become sick, and two prosecutors, who appear to say nothing.) The four defendants sit to the Court's left hand in a line perpendicular to the judges' bench, and behind their lawyers. Although the legal people are distinguishable by their mostly shabby gowns (no wigs), others take off their jackets when the temperature rises.

The chief defendant, Dr Michel Garretta, who became director of the National Centre for Blood Transfusion (CNTS) in October 1984 , is slightly built and is made to seem even slighter by the gendarmes who sit on either side of him, their pill-box hats giving them an extra $10 \mathrm{~cm}$ or so; they are there because Garretta travels each day from the prison at which he began serving his four-year sentence last October. $\mathrm{He}$, no doubt, will be sorry when the trial ends.

But there is very little communication between him and his co-defendants. No longer are they close colleagues. Indeed, part of the reason why they are now in the dock is that they seem never to have been close. Last Wednesday, Garretta sat with hands folded listening attentatively to a remarkable histrionic performance by Maître Olivier Schnerb, the lawyer representing Dr Jean-Pierre Allain, previously director of research at CNTS, but now a professor in the department of haematology at the University of Cambridge. Allain was sentenced to four years' imprisonment, two of them suspended, last October; he appealed within a day.
The circumstances of this second trial are curious in themselves. After two appeals, the court elected to hear the whole case again. The other defendants are Professor Jacques Roux, in 1985 directorgeneral of health in the National Ministry of Health (given a four-year suspended sentence last year) and Dr Robert Netta, director-general of the National Laboratory of Health (who was acquitted). In principle, the retrial could bring more severe sentences for some of the defendants. In practice, the outcome is likely to be leniency.

That the affair of the contaminated blood is a scandal cannot be denied, and is not. So much has been crystal clear since the publication in September 1991 of a report by Michel Lucas, the inspector-general of social affairs, whose report amply documented the reasons why, between the spring of 1984 (when HIV was well characterized serologically) and 1 October 1985, the steps that could have been taken to protect patients with haemophilia from blood products derived from contaminated blood were not taken. The CNTS, given the status of a private foundation a decade earlier but still controlled by the government, and with a monopoly on the import of blood and blood products into France, was necessarily at the centre of the affair.

The Lucas report spelled out the way in which approval for the blood tests for HIV developed in the United States in 1984 was deliberately held up so that the alternative under development at the Pasteur Institute could catch up; that was crucial at a time when the only means of screening blood donors was verbal enquiry into their lifestyle. When, later that year, it emerged that 6 per cent of blood donors in Paris were infected with HIV, Garretta calculated that the chance that all pools of blood collected in Paris were not contaminated must be less than one in a thousand.

Another element in the scandal was the delay in subjecting contaminated blood to the heat-treatment by then known to be effective in removing the risk of infection by hepatitis B. By the end of 1983 , CNTS was negotiating with Immuno (of Austria) about the possibility of treating its existing stocks of blood, but delayed a decision (and responded only with delay to an offer by the blood products centre at Lille to collaborate on the heat-treatment of all blood used for transfusion and the manufacture of blood products in France).
During the summer of 1985 , while Allain was conducting a controlled trial of the consequences of using heat-treated and untreated Factor VIII for administration to haemophiliacs, CNTS promulgated the rule that treated blood products (then being imported from the United States) should be reserved for haemophiliacs showing no signs of antibodies against HIV antigens, and that those which had already seroconverted (roughly half) should be given untreated Factor VIII "while stocks last". In May 1985, it was decided that the French health service would no longer meet the cost of untreated Factor VIII after 1 October.

Among the circumstances contributing to this delay identified by Lucas and the judgement of the first trial were Garretta's view of CNTS as an industrial enterprise founded on French research and the incestuous relationship between CNTS and the French Association of Haemophiliacs (AFH), representing physicians concerned with the treatment of haemophiliacs. The judgement of the first trial complains that AFH, whose secretariat and office space were provided by CNTS, was never told with sufficient clarity that all stocks of blood collected in France were probably contaminated with HIV.

The human tragedy is immense. Half of France's 6,000 haemophiliacs were infected with HIV, perhaps 1,200 of them during the period when they might have been protected. Why should the anger generated give way to leniency? One powerful consideration is that those on trial are only a subset of those involved in the decision. Schnerb likened them (or at least his client) to people who had reported a tragic road accident to the police, and had been arrested for their pains.

All those arraigned are on record during 1984 and 1985 as having warned others of the dangers of using contaminated blood. The doubt is whether they warned the right people, and with sufficient urgency. Schnerb last Wednesday, on behalf of Allain, had no doubt. His client was a "visionary", who among other things had written to Garretta in January 1985 to urge immediate steps to heat-treat the contaminated blood. "If you condemn him now", Schnerb insisted, nobody will ever again write such a courageous letter. But his most telling point remained the claim that there should have been a hundred defendants, not just four. It is the system that is on trial.

John Maddox 